УДК 338.004 (477)

DOI: 10.35340/2308-104X.2020.86-1-23

\section{ФОРМУВАННЯ ДЕРЖАВНОЇ \\ ПОЛІТИКИ ЦИФРОВІЗАЦІЇ \\ ЕКОНОМІКИ: ЗАКОРДОННИЙ ДОСВІД}

\section{FORMATION OF THE STATE POLICY OF DIGITALIZATION OF ECONOMY: FOREIGN EXPERIENCE}

\author{
ОСТРОВИЙ О. В., \\ кандидат наук державного \\ управління, керівник відділу \\ аналізу та пропаганди, \\ Департамент верифікації \\ декларацій та моніторингу \\ способу життя, Національне \\ агентство 3 питань запобігання \\ корупції
}

OSTROVYJ O.,

PhD in Public Administration, the Head of the Analysis and Outreach Division, the Department of Declaration Verification and Lifestyle Monitoring, National Agency on Corruption Prevention

Визначено роль державного регулювання у сфері ичифровізації начіональної економіки. Досліджено сучасні тенденщії розвитку цифрової економіки в різних країнах. Проаналізовано закордонний досвід формування державної політики ичифровізачї̈, який представляє інтерес для імплементації в Україні.

Ключові слова: державна політика; державне регулювання; цифровізація; иифрова економіка; закордонний досвід.

Определена роль государственного регулирования в сфере ичифровизации национальной экономики. Исследовань современнье тенденции развития циирровой экономики в разных странах. Проанализирован зарубежный опыт формирования государственной политики ичифровизации, представляющий интерес для имплементации в Украине.

Ключевые слова: государственная политика; государственное регулирование; цифровизация; цифрровая экономика; зарубежный опыт.

The role of state regulation in the field of digitalization of the national economy is determined. The current trends in the development of the digital economy in different countries have been investigated. The foreign experience of forming the state policy of digitalization, which is of interest for implementation in Ukraine, is analyzed.

Keywords: government policy; state regulation; digitalization; digital economy; foreign experience

Постановка проблеми. Сьогодні цифрові технології, проникаючи в різні сфери діяльності, відіграють значну роль у розвитку економік країн світу, відкривають нові можливості для зростання їх конкурентоспроможності та підвищення якості життя громадян. 
Фахівці Світового банку звертають увагу на той факт, що такі технології здатні сприяти подоланню соціальної ізоляції, підвищенню продуктивності праці, впровадження інновацій [1]. Використовуючи економію від масштабу та мережевих ефектів, вони створюють додаткові можливості для економічного росту країн, які розвиваються [2].

Однак, слід констатувати, що цифровізація економіки, яка має стати пріоритетним вектором для України, основним напрямом інноваційного розвитку та інструментом створення довгострокових конкурентних переваг, здійснюється дещо повільно. Основна причина такого стану відсутність стратегічного бачення ситуації та дієвої системної державної політики у цій сфері.

Слід звернути увагу, що міжнародний досвід підтверджує провідну роль держави в процесах цифровізації економіки. Крім того, провідні країни світу вже мають певні напрацювання стосовно запровадження інструментів державного регулювання в цій сфері.

Отже, формування стратегічних засад цифрових трансформацій в країні, курс на інтеграцію в Сдиний цифровий ринок ЄС актуалізують питання дослідження позитивного закордонного досвіду формування державної політики цифровізації та вивчення можливості його імплементації в Україні.

Аналіз останніх досліджень $і$ публікацій. Базові концептуальні засади цифровізації економіки досліджено в працях Н. Негропонте [3], Д. Тапскотта [4].

Сучасні тенденції розвитку цифрової економіки та окремі аспекти регулювання цих процесів розглянуто в роботах вітчизняних та закордонних вчених. Серед них: А. Мк. Афее, Д. Боннет [5], Е. Бринолфссон [6], Дж. Вестерман [5], О. Данченко [7], Д. Еванс [8], Ю. Корнєєва [9].

Однак, питання регуляторного впливу держави на процеси цифровізації економіки в провідних країнах світу потребують додаткового вивчення. Це дозволить адаптувати найкращі світові практики до вітчизняних умов, стимулювати розвиток інновацій та трансформаційні процеси в національній економіці.

Метою статmі $є$ аналіз закордонного досвіду формування державної політики розвитку цифрової економіки, який представляє інтерес для імплементації в Україні.

Виклад основного матеріалу дослідження. Сучасним пріоритетом для провідних країн світу є розвиток цифрової економіки, яка на відміну 
від традиційної, визначається «мережевою свідомістю та залежністю від віртуальних технологій» [4]. Поштовхом для цих процесів стало запровадження відповідних технологій та інновацій.

Стрімкий розвиток інформаційно-комунікаційних технологій сприяв зростанню світового показника кількості користувачів мережі Інтернет до 4,021 млрд осіб (55,6\%) від усього населення Землі (табл. 1) та формуванню інформаційного суспільства.

Таблиця 1

Використання мережі Інтернет у світі та статистика населення (на 31.122018 р.)

\begin{tabular}{|c|c|c|c|c|c|c|}
\hline & \multicolumn{2}{|c|}{ Населення } & \multicolumn{4}{|c|}{ Користувачі мережі Інтернет } \\
\hline & $\begin{array}{l}\text { кількість, } \\
\text { осіб }\end{array}$ & $\begin{array}{c}\text { \% до } \\
\text { загальної } \\
\text { кількості }\end{array}$ & $\begin{array}{l}\text { кількість, } \\
\text { осіб }\end{array}$ & $\begin{array}{l}\text { питома } \\
\text { вага, \% }\end{array}$ & $\begin{array}{c}\text { рівень } \\
\text { проникнення } \\
\text { (\% до кількості } \\
\text { населення) }\end{array}$ & $\begin{array}{c}\text { темп } \\
\text { зрост } \\
\text { ання } \\
2000- \\
2018, \\
\%\end{array}$ \\
\hline $\begin{array}{l}\text { Країни } \\
\text { Африки }\end{array}$ & 1320038716 & 17,0 & 464923169 & 10,8 & 35,2 & 10199 \\
\hline Країни Азії & 4241972790 & 54,7 & 2160607318 & 50,1 & 50,9 & 1790 \\
\hline $\begin{array}{l}\text { Країни } \\
\text { Європи }\end{array}$ & 866433007 & 11,2 & 705064923 & 16,3 & 81,4 & 571 \\
\hline $\begin{array}{c}\text { Латинська } \\
\text { Америка }\end{array}$ & 658345826 & 8,5 & 438248446 & 10,2 & 66,6 & 2325 \\
\hline $\begin{array}{c}\text { Країни } \\
\text { Середнього } \\
\text { Сходу }\end{array}$ & 258356867 & 3,3 & 170039990 & 3,9 & 65,8 & 5076 \\
\hline $\begin{array}{l}\text { Північна } \\
\text { Америка }\end{array}$ & 366496802 & 4,7 & 345660847 & 8,0 & 94,3 & 219 \\
\hline Австралія & 41839201 & 0,5 & 28437577 & 0,7 & 68,0 & 273 \\
\hline Разом у світі & 7753483209 & 100 & 4312982270 & 100 & 55,6 & 1095 \\
\hline
\end{tabular}

Джерело: складено автором за даними [10]

Однак, слід констатувати, що розповсюдження таких інновацій між окремими країнами та континентами характеризується значною асиметрією. Так, найбільший рівень проникнення Інтернет - у країнах Свропи $(81,4 \%)$ та Північній Америці (94,3\%). Найменший - у країнах Африки (35,2\%). 
Враховуючи кількість населення, найбільший відсоток Інтернеткористувачів в масштабах планети - у країнах Азї (50,1\%), найменший - в Австралії $(0,7 \%)$.

В сучасній світовій практиці з метою визначення, подолання бар'єрів та підвищення конкурентних переваг, в тому числі і у сфері цифровізації, застосовуються різні міжнародні рейтинги, які базуються на інтеграції різноманітних показників та розрахунку відповідних індексів. Серед основних з них: індекс розвитку IKT (IDI); глобальний індекс кібербезпеки (GCI-ITU); індексу цифрової еволюції (DEI); швидкості впровадження інновацій; індекс цифрової економіки та суспільства (DESI); індекс світової цифрової конкурентоспроможності (WDCI) тощо.

Так, використання індексу цифрової еволюції (DEI) та швидкості впровадження інновацій дозволило виділити певні групи країн за рівнем розвитку цифрової економіки (табл. 2).

Таблиця 2

Групи країн за рівнем розвитку цифрової економіки

\begin{tabular}{|c|c|c|}
\hline Назва групи & Характерні риси & Країни \\
\hline $\begin{array}{l}\text { Stand out («Які } \\
\text { виділяються») }\end{array}$ & $\begin{array}{l}\text { Високий рівень цифрової економіки та швидке } \\
\text { впровадження інновацій. Однак, існують } \\
\text { труднощі збереження стабільно високої } \\
\text { позитивної динаміки у перспективі, що } \\
\text { вимагає акумулювання нових зусиль }\end{array}$ & $\begin{array}{l}\text { Гонконг, Сінгапур, } \\
\text { Великобританія, } \\
\text { ОАЕ, } \quad \text { Ізраїль, } \\
\text { Латвія, } \\
\text { Малайзія }\end{array}$ \\
\hline $\begin{array}{l}\text { Stall out («Які } \\
\text { затухають») }\end{array}$ & $\begin{array}{l}\text { Високий рівень розвитку цифрової економіки } \\
\text { на фоні невисоких темпів впровадження } \\
\text { iнновацій, що потребує вдосконалення } \\
\text { iнноваційних систем }\end{array}$ & $\begin{array}{l}\text { Норвегія, Швеція, } \\
\text { Швейцарія, Данія, } \\
\text { Фінляндія }\end{array}$ \\
\hline $\begin{array}{l}\text { Break out } \\
\text { («Спалахуючі») }\end{array}$ & $\begin{array}{l}\text { Невисокий рівень розвитку цифрової } \\
\text { економіки, але висок швидкість впровадження } \\
\text { інновацій, що робить іх привабливими для } \\
\text { інвесторів. Основний бар'єр - слабкий рівень } \\
\text { розвитку інфраструктури та низька якість } \\
\text { інновацій }\end{array}$ & $\begin{array}{l}\text { Польща, } \\
\text { Туреччина, } \\
\text { Філіппіни, } \\
\text { Марокко, Росія, } \\
\text { Індія, } \\
\text { В'єтнам }\end{array}$ \\
\hline $\begin{array}{l}\text { Watch Out («Ti, } \\
\text { що очікують») }\end{array}$ & $\begin{array}{l}\text { Низький рівень інноваційного розвитку на } \\
\text { фоні низьких темпів впровадження інновацій } \\
\text { зазнають найбільші труднощі в процесі } \\
\text { розвитку цифрової економіки) }\end{array}$ & $\begin{array}{l}\text { Перу, } \quad \text { Сгипет, } \\
\text { Пакистан, } \\
\text { Словаччина, ПАР }\end{array}$ \\
\hline
\end{tabular}

Джерело: [11]

Міжнародний досвід свідчить, що на шляху цифровізації економіки країни стикаються зі значною кількістю викликів та проблем, які потребують своєчасного вирішення. Серед основних з них слід відзначити наступні: рівень розвитку інфраструктури та доступу до необхідних даних; 
належний ступінь забезпечення кібербезпеки; формування необхідної нормативно-правової бази; стимулювання інвестиційних процесів тощо.

Але потенціал цифрових трансформацій для розвитку національних економік відзначено як на міжнародному рівні, так і урядами країн. 32016 р. країни «Великої сімки» та «Великої двадцятки» включили це питання як ключове до порядку денного своїх самітів, усвідомлюючи, що «... цифровізація здатна докорінно перетворити наше життя, забезпечуючи процвітання націй» [12].

Необхідно звернути увагу, що державна політика цифровізації економіки в Європейському Союзі (СС) здійснюється на основі стратегічного підходу, який запроваджується на національному та наднаціональному рівнях. Він передбачає формування та реалізацію стратегій розвитку - «цифрових адженд», які спрямовані на розвиток економік країн на засадах цифровізації та формування Сдиного цифрового ринку ЄС. На наднаціональному рівні в СС затверджена «Цифрова стратегія Європа 2020», яка передбачає масове впровадження Інтернет технологій.

Слід констатувати, що характерною особливістю світового цифрового розвитку $є$ міжнародне співробітництво та інтеграція, що проявляється у досягненні сумісності стандартів, протоколів та інтерфейсів.

Зазначимо, що формування та реалізація державної політики в одній чи декількох сферах здійснюється відповідними міністерствами. Першою країною в якій було створено Міністерство цифрової економіки як державний інститут, що відповідає за управління процесами цифровізації країни та впроваджено широке, масштабне використання «хмарних технологій» зі створенням «Дата центрів» «G. Glouds» стала Великобританія [9, с. 122]. Слід відзначити, що саме ця країна сьогодні демонструє найкращі результати розвитку в сфері інновацій та інформаційних технологій на міжнародній арені.

Державне регулювання розвитку цифрової економіки в країнах ЄС базується переважно на економічних інструментах, максимально зменшуючи використання адміністративних методів. Така політика реалізується через стимулювання інвестиційних процесів (запровадження онлайн-порталів та онлайн-вікон, де потенційні інвестори можуть отримати необхідну інформацію щодо розвитку відповідних процесів та консультації стосовно законодавства в сфері інвестування); зменшення торгівельних обмежень між країнами $\mathrm{CC}$; створення умов для спрощення 
реєстрації бізнесу; зниження ліцензійних та дозвільних обмежень для розвитку електронного бізнесу тощо.

Сьогодні у світі активно впроваджуються системи електронного урядування, які дозволяють забезпечити взаємодію держави та бізнесу на засадах прозорості i публічності шляхом впровадження систем електронного регулювання та електронної реєстрації (здійснення державної реєстрації підприємств, організація документообігу та звітності тощо).

Так, за даними Конференції ОOH з торгівлі та розвитку (UNCTAD) на кінець 2017 р., державні платформи для надання публічної інформації та послуг впроваджено більш ніж у 90 країнах світу, а надання окремих онлайн-послуг здійснюється у 148 країнах [13].

Крім того, урядами розвинутих країн одними 3 основних векторів розвитку економіки визначено цифрову трансформацію основних галузей промисловості, яка повинна бути спрямована на підвищення їх ефективності, продуктивності та конкурентоспроможності на міжнародній арені.

На національному рівні це втілюється на основі програмного підходу шляхом розробки та запровадження відповідних програм, в яких визначено основні задачі та комплекси заходів щодо впровадження та використання нових цифрових технологій в різних галузях економіки. Серед основних 3 них слід відзначити наступні: «Партнерство 3 передового виробництва» («Advanced Manufacturing Partnership») та «Консорціум промислового інтернету» («Industrial Internet Consortium») в США, «Industry 4.0» в Німеччині, «Фабрики Майбутнього» («Factories of the Future») в країнах CC, «Зроблено в Китаї 2025» («Made in China 2025») тощо. Фінансування таких проєктів здійснюється переважно на основі державно-приватного партнерства.

Практична реалізація цих задач здійснюється шляхом технологічних змін, які супроводжуються впровадженням інтелектуальних систем, які сприяють трансформації традиційного виробництва в цифрове i характеризуються повною цифрової інтеграцією виробничих і логістичних ланцюжків, а також ланцюгів поставок та принципово нових бізнеспроцесів на всіх рівнях виробництва, здатних забезпечити в найкоротші терміни проєктування і виробництво конкурентоспроможної продукції нового покоління. 
Слід відзначити, що у сучасній світовій практиці значна увага приділяється розвитку цифрового підприємництва та міжнародного бізнесу, в тому числі на основі цифрових платформ [14].

Так, Свропейська комісія серед основних п'яти напрямів програми цифрового підприємництва відзначає розвиток цифрових знань та ринку; створення цифрового бізнес-середовища; спрощення доступу до фінансів для бізнесу; формування та розвиток цифрових навичок працюючих; та створення підтримуючої культури [7].

При цьому серед основних інструментів державного регулювання, які спрямовані на стимулювання цих процесів слід виокремити наступні: гармонізація нормативно-правової бази, в тому числі в галузі технічного захисту інформації; сприяння міжнародній електронній торгівлі; розвиток інформаційно-комунікаційних та цифрових технологій, відповідної інфраструктури. Досвід провідних країн світу доводить ефективність такої політики, що обумовлено усуненням надлишкових посередницьких ланок, зменшенням собівартості продукції та вартості транзакцій, прискоренням оборотності коштів та підвищенням ефективності процесів.

Висновки $i$ перспективи подальших досліджень. Дослідження світового досвіду дозволяє констатувати, що цифрові технології домінують у всіх сферах світового господарства та суспільного життя, а цифровізація виступає одним з основних інструментів розвитку економіки.

Значну роль в цих процесах відіграє дієва державна політика. Провідні країни світу вже мають певні напрацювання щодо державного регулювання в цій сфері, яке базується переважно на економічних інструментах, максимально зменшуючи використання адміністративних методів.

Визначені інструменти та заходи представляють інтерес для адаптації в Україні з метою формування ефективної державної політики, спрямованої на подальший розвиток цифрової економіки. Однак, їх імплементація потребує формування відповідних механізмів (правового, економічного, організаційного тощо), що складає перспективи подальших досліджень.

\section{Jimepamypa:}

1. World Bank Group. World Development Report 2016: Digital Dividends. Washington, DC: World Bank, 2016. 330 p. 
2. Dahlman C., Mealy S., Wermelinger M. Harnessing the digital economy for developing countries. OECD Development Centre Working Papers. OECD Publishing. Paris, 2016. No. 334. 80 p.

3. Negroponte N. Being Digital. New York, Alfred A. Knopf, 1995. $243 \mathrm{p}$.

4. Tapscott D. The Digital Economy: Promise and Peril in the Age of Networked Intelligence. New York: McGraw-Hill, 1995. 342 p.

5. Brynjolfsson E., Kahin B. Understanding the Digital Economy: Data, Tools, and Research [reprint]. USA: MIT Press, 2002. 407 p.

6. Westerman G., Bonnet D., McAfee A. Leading Digital: Turning Technology into Business Transformation. USA: Harvard Business School Publisher, 2014. 292 p.

7. Данченко О. Україні варто взяти за озброєння досвід Британії щодо впровадження цифрової економіки. URL: https:// apostrophe.ua/ua/news/ economy/2017-02- 01/danchenko/85328.

8. Evans D. The Internet of Things: How the Next Evolution of the Internet Is Changing Everything. CISCO White Paper. April 2011. URL: http://www.ciscocom/web/about/ac79/docs/innov/IoT_IBSG_0411FINAL.pdf.

9. Корнєєва Ю. В. Роль держави у сприянні інвестиціям у розвиток цифрової економіки. Економіка прогнозування. 2018. № 1. С. 120-134.

10. Internet World Stats. URL: https://www.internetworldstats.com /stats.htm.

11. Смирнов Е. Н. Цифровая трансформация мировой экономики: торговля, производство, рынки: монография. URL: https://izd-mn.com/PDF/ 38MNNPM19.pdf.

12. OECD Digital Economy Outlook 2017. URL: http://www.oecd.org/ internet/oecd-digital-economyoutlook-2017-9789264276284-en.htm.

13. World Investment Report 2017: Investment and digital economy. UNCTAD, 2017. URL: https://unctad.org/en./publicationslibrary/wier2017_en / pdf.

14. Galkin A., Popova Y., Chuprina E., Shapovalenko D. Interaction of logistics 4.0 and consumer oriented marketing using ICT. Proceedings of the 33rd International Business Information Management Association Conference, IBIMA 2019: Education Excellence and Innovation Management through Vision 2020. Granada, 2019. C. 6751-6760.

\section{References:}

1. World Bank Group. World Development Report 2016: Digital Dividends. Washington, DC: World Bank, 2016. 330 p. 
2. Dahlman C., Mealy S., Wermelinger M. Harnessing the digital economy for developing countries. OECD Development Centre Working Papers. OECD Publishing. Paris, 2016. No. 334. 80 p.

3. Negroponte N. Being Digital. New York, Alfred A. Knopf, 1995. $243 \mathrm{p}$.

4. Tapscott D. The Digital Economy: Promise and Peril in the Age of Networked Intelligence. New York: McGraw-Hill, 1995. 342 p.

5. Brynjolfsson E., Kahin B. Understanding the Digital Economy: Data, Tools, and Research [reprint]. USA: MIT Press, 2002. 407 p.

6. Westerman G., Bonnet D., McAfee A. Leading Digital: Turning Technology into Business Transformation. USA: Harvard Business School Publisher, 2014. 292 p.

7. Danchenko O. Ukraini varto vziaty za ozbroiennia dosvid Brytanii shchodo vprovadzhennia tsyfrovoi ekonomiky. URL: https:// apostrophe.ua/ua/news/ economy/2017-02- 01/danchenko/85328.

8. Evans D. The Internet of Things: How the Next Evolution of the Internet Is Changing Everything. CISCO White Paper. April 2011. URL: http://www.ciscocom/web/about/ac79/docs/innov/IoT_IBSG_0411FINAL.pdf.

9. Kornieieva Yu. V. Rol derzhavy u spryianni investytsiiam u rozvytok tsyfrovoi ekonomiky. Ekonomika prohnozuvannia. 2018. \# 1. S. 120-134.

10. Internet World Stats. URL: https://www.internetworldstats.com /stats.htm.

11. Smirnov E. N. Tsifrovaya transformatsiya mirovoy ekonomiki: torgovlya, proizvodstvo, rynki: monografiya. URL: https://izd-mn.com/PDF/ 38MNNPM19.pdf.

12. OECD Digital Economy Outlook 2017. URL: http://www.oecd.org/ internet/oecd-digital-economyoutlook-2017-9789264276284-en.htm.

13. World Investment Report 2017: Investment and digital economy. UNCTAD, 2017. URL: https://unctad.org/en./publicationslibrary/wier2017_en / pdf.

14. Galkin A., Popova Y., Chuprina E., Shapovalenko D. Interaction of logistics 4.0 and consumer oriented marketing using ICT. Proceedings of the 33rd International Business Information Management Association Conference, IBIMA 2019: Education Excellence and Innovation Management through Vision 2020. Granada, 2019. C. 6751-6760. 
The purpose of the article is to analyze the foreign experience of forming the state policy of digital economy development, which is of interest for implementation in Ukraine.

It is noted that digital technologies play a significant role in the development of economies around the world, open new opportunities for increasing their competitiveness and improving the quality of life of citizens.

The leading role of the state in the processes of digitalization of the economy is determined.

It is established that the rapid development of information and communication technologies has contributed to the growth of the global number of Internet users to 4.021 billion people $(55.6 \%)$ of the total population of the Earth (Table 1) and the formation of the information society. However, the spread of such innovations between individual countries and continents is characterized by significant asymmetry. Thus, the highest level of Internet penetration is in Europe (81.4\%) and North America (94.3\%). The lowest - in Africa (35.2\%).

Current trends in the digital economy in different countries are studied. Groups of countries by level of development of digital economy are allocated.

The foreign experience of formation of the state policy of digitalization is analyzed. It is noted that they already have some experience in state regulation of digitalization processes in the leading countries of the world, mainly based on economic instruments, minimizing the use of administrative methods.

Namely: development and implementation of strategies and programs; stimulation of investment processes; infrastructure development, information and communication and digital technologies; introduction of e-government; promoting the digitalization of industry and entrepreneurship; reduction of trade restrictions between countries; harmonization of the regulatory framework, including in the field of technical protection of information; promotion of international e-commerce, etc.

The identified tools and measures are of interest for adaptation in Ukraine in order to form an effective public policy aimed at further development of the digital economy. 